\title{
Powtórna i wielokrotna wiktymizacja jako andragogiczny wymiar doświadczeń osobistych kobiet ofiar przemocy
}

\author{
Repeated and multiple victimization as an andragogical \\ dimension of the personal experiences of the female victims \\ of violence
}

\begin{abstract}
Streszczenie. Problematyka doświadczeń przemocowych, a właściwie następstw tych wydarzeń, omawiana jest w różnych kontekstach. Jedną z najistotniejszych kwestii jest wskazanie całożyciowych następstw tych doświadczeń, jakie pojawiać się mogą u kobiet, które dopuściły się zabójstwa partnera życiowego, a ujawniających się w postaci problemów osobowościowych ujawniających się w postaci niskiej samooceny, poczucia winy, stanów lękowych, depresji, podejrzliwości, utraty nadziei, odrętwienia uczuciowego, poczucia piętna oraz problemów $\mathrm{w}$ interakcjach $\mathrm{z}$ innymi ludźmi. Zmianom tożsamościowym towarzyszy zwykle stan wyuczonej bezradności ograniczający możliwości wydostania się z traumatycznych relacji. Głównym celem opracowania była analiza następstw doświadczanej przez kobiety przemocy, a w szczególności wskazanie specyfiki kształtowania się procesu wiktymizacji powtórnej i wielokrotnej oraz skutków, jakie proces ten wywołuje w toku ich życia wpływając na autokreację i definiowanie tożsamości ofiary. W badaniach wykorzystano metodę przeszukiwania źródeł wtórnych. Proces wiktymizacji zapoczątkowany jest doświadczeniami traumatycznymi zwykle o charakterze przemocowym. W opracowaniu zostały scharakteryzowane konsekwencje, jakie stają się udziałem ofiary przechodzącej przez kolejne fazy procesu wiktymizacji pierwotnej i powtórnej. Powodują one coraz głębsze zmiany tożsamości, które okazują się w większości przypadków zmianami nieodwracalnymi. Ofiary doświadczają objawów syndromu wyuczonej bezradności, syndromu bitej żony, efektu psychologicznej pułapki czy syndromu sztokholmskiego. Opisane zostały także mechanizmy obronne charakterystyczne dla ofiar, które blokują możliwość obrony przed traumatycznymi doświadczeniami. Często nieuniknionym skutkiem jest naprzemienna identyfikacja, podczas której ofiara wchodzi w rolę sprawcy.
\end{abstract}


Słowa kluczowe: ofiara, wiktymizacja, wiktymizacja powtórna, mechanizmy obronne, naprzemienna identyfikacja

Summary. The issue of violent experiences and actually the consequences of these events is discussed in different contexts. One of the most important issues is to indicate lifetime stock consequences of these experiences which can appear in women who have committed murder for a life partner, and revealing in the form of personality problems manifest themselves in the form of low self-esteem, guilt, anxiety, depression, suspicion, loss of hope, emotional numbness, a sense of stigma and problems in interactions with other people. Change of identity is usually accompanied by state of learned helplessness limiting the possibility of escaping from the traumatic relationship. The main objective of the study was to analyze the consequences of violence experienced by women, and in particular an indication of the specifics of the formation of the process of revictimization and multiple and the effects that this process produces in the course of their lives affecting the self-creation and definition of the identity of the victim. The study used the method of searching secondary sources. The process of victimization is initiated traumatic experiences usually to violent character. The study has been characterized have consequences that are involving the victims through the successive phases of the process and the revictimization of the original. They cause a deeper change of identity, which turn out to be, in most cases the changes irreversible. Victims are experiencing symptoms of the syndrome of learned helplessness syndrome whipped his wife, the effect of psychological traps or Stockholm syndrome. Have been described as defense mechanisms characteristic of the victims, which block the ability to defend against traumatic experiences. Often, the inevitable result is alternating identification, during which the victim comes to the role of the perpetrator.

Keywords: the victim, victimization, revictimization, defense mechanisms, alternating identification

\section{Wprowadzenie}

Problem andragogicznego wymiaru doświadczeń osobistych prowadzących do wiktymizacji, o którym mowa będzie w niniejszym artykule, nakreślony zostanie w kontekście procesualności doświadczeń przemocowych kobiet, u których nastąpiła identyfikacja z rolą ofiary i naprzemienna identyfikacja ról. Zwykle początkiem procesu są doświadczenia przemocowe z okresu dzieciństwa lub początku trwania związku, które określić można jako wiktymizację pierwotną. Jej skutkiem jest internalizacja nieadekwatnych mechanizmów i strategii obronnych, które jako utrwalone sposoby zachowania w sytuacjach trudnych sprzyjają powtórnej, a nawet wielokrotnej wiktymizacji w życiu dorosłym. Jedną z konsekwencji tego procesu jest naprzemien- 
ność ról ofiary i sprawcy, co oznacza możliwość wejścia doświadczającej wiktymizacji kobiety w rolę sprawczyni.

Zjawisko przemocy, a w szczególności przemocy domowej (lub przemocy w rodzinie czy w wąskim ujęciu przemocy partnerskiej), które w kontekście omawianego problemu stanowi główne źródło wiktymizacji, interpretowane jest w zróżnicowany sposób, choć zwykle dość szeroko i nieprecyzyjnie. M. Budyn-Kulik pod pojęciem przemocy w rodzinie rozumie: „zachowania naganne, acz nie zawsze prawnie relatywne, podejmowane przez jednego członka rodziny wobec innych" (Budyn-Kulik, 2005, s. 52). Zawężenie kontekstu przemocy do zachowań w obrębie diady partnerskiej nie oddaje istoty problemu. Zjawisko to bowiem nie obejmuje wyłącznie partnerów w związku, ale dotyczy także, bezpośrednio lub pośrednio, również innych członków rodziny. Z tego powodu można zaryzykować stwierdzenie, że przemoc domowa staje się doświadczeniem osobistym wszystkich jej członków, nawet jeśli bezpośrednio ich nie dotyka. Niekiedy następstwem stosowania przemocy domowej może być śmierć członka rodziny. Śmierć ta, zostaje zadana w sposób umyślny bądź nieumyślny. Może być ona celem świadomie branym pod uwagę przez sprawcę lub też może on jej po prostu nie wykluczać. W takiej sytuacji działania sprawcy poprzedzone są długotrwałym maltretowaniem ofiary, dążeniem do całkowitego podporządkowania. Śmierć może być także skutkiem niezamierzonym i stanowić skrajny przejaw wiktymizacji ofiary, która doprowadzając do śmierci sprawcy przemocy czyni to często w obronie własnej, wchodząc tym samym w rolę sprawcy. Sugeruje się, żeby "całokształt relacji sprawca - ofiara ujmować jako proces kryminologiczny (stawania się przestępcą) i proces wiktymizacji (stawania się ofiara)" (Majchrzyk, 2008, s. 224).

\section{Cel i metoda}

W niniejszym opracowaniu chciałabym odnieść się do całożyciowych konsekwencji, jakich doświadczają kobiety będące ofiarami przemocy. Konsekwencje te powiązane są ze wspomnianym procesem wiktymizacji, który rozpoczyna się zazwyczaj w momencie zaistnienia przemocy, ale nie kończy się z chwilą jej ustania. Proces wiktymizacji wpływa na zmianę tożsamości ofiary przede wszystkim zmieniając wizję własnej osoby. Wiktymizacja kształtuje, a właściwie wypacza charakter relacji z innymi osobami, deprecjonuje poczucie własnej wartości. Jednym z przejawów nowej tożsamości jest wyuczona bezradność powodująca, że ofiara „uczy się” nowych sposo- 
bów pełnienia dotychczasowych ról, w których dominuje poczucie bezradności, zależności od sprawcy i zamkniętej przyszłości. Spirala wiktymizacji nie dotyczy tylko kobiet zależnych ekonomicznie od partnera czy niepracujących, wyuczona bezradność będąca skutkiem wiktymizacji może dotknąć kobiety wykształcone, samodzielne finansowo, pozornie niezależne. W przypadku niektórych kobiet wydarzenia przemocowe, jak i wskazane konsekwencje doprowadzają do ekstremalnych wydarzeń, jakimi jest spowodowanie śmierci partnera, sprawcy przemocy. W tym przypadku śmierć ta jest, jak wspomniano, skutkiem zwykle niezamierzonym, będącym wynikiem długotrwałego maltretowania ofiary, która na skutek zmian osobowościowych spowodowanych procesem wiktymizacji, wchodzi w rolę sprawcy.

Celem niniejszego opracowania jest zatem omówienie następstw doświadczanej przez kobiety przemocy, a w szczególności wskazanie specyfiki kształtowania się procesu wiktymizacji powtórnej i wielokrotnej oraz skutków, jakie proces ten wywołuje w toku ich życia. Niestety nie są to konsekwencje pozytywne, jednak również wpływające na proces autokreacji i definiowania tożsamości ofiary.

Analiza podjętej problematyki opierać się zatem będzie na ustaleniu w oparciu o literaturę następujących kwestii:

1 Omówienie przebiegu procesu wiktymizacji i jego konsekwencji psychologicznych $w$ postaci zinternalizowanych mechanizmów obronnych i zmian tożsamości prowadzacych do powtórnej i wielokrotnej wiktymizacji

2 Przedstawienie zasadniczych cech procesu naprzemiennej identyfikacji jako źródła transgeneracyjności przemocy

Opracowanie ma charakter teoretyczny, zatem wykorzystaną metodą jest przeszukiwanie źródeł, które stanowiły opracowania teoretyczno-empiryczne i specjalistyczne (poddane następnie analizie) (zob. Rubacha, 2008).

\section{Proces wiktymizacji i jego następstwa*}

Z punktu widzenia wiktymologii pojęcie ofiary interpretować można dość szeroko. Najogólniej pod tym pojęciem można rozumieć osoby, które doświadczyły krzywdy lub szkody. Natomiast wiktymizacja ma miejsce w obrę-

* W opracowaniu tej części wykorzystano fragmenty książki M. H. Kowalczyk i A. Latoś „Żony, matki - zabójczynie. Studium zwiktymizowanej zbrodni”, Wydawnictwo UMK, Toruń 2016. 
bie zagmatwanych okoliczności lub może być rezultatem stosunków, które są w równym stopniu złożone (Hołyst, 2006, s. 60). Inaczej mówiąc wiktymizacja to doznawanie krzywd i szkód w wyniku jakiegoś zdarzenia o charakterze krzywdzącym, które może być inicjowane przez drugiego człowieka. W sytuacji doświadczania przemocy nie można mówić o jednorazowym doświadczeniu wiktymizacyjnym osoby ulegającej przemocy, lecz o procesie stawania się ofiarą lub procesie wchodzenia w rolę ofiary. Jerzy Mellibruda wskazuje, że u ofiar przemocy domowej, często rozwija się tzw. proces wiktymizacji, który zmienia poczucie tożsamości maltretowanej osoby (Mellibruda, 2009, s. 28). Nie bez przyczyny wskazuje się na procesualność wiktymizacji. W odróżnieniu od ofiar innych rodzajów przestępstw, które doświadczać mogą traumatycznego wydarzenia raz, ofiara przemocy partnerskiej (czy szerzej domowej) ulega traumatycznym doświadczeniom systematycznie. Powoduje to powolne przekształcanie się jej osobowości. Następuje burzenie utrwalonych przekonań. Początkowo osoba doznająca przemocy ma poczucie krzywdy, czuje rozpacz, lęk, często na tym etapie zaczyna szukać pomocy. Jeśli jej działania napotykają na mało przychylne reakcje wynikające $z$ obojętności, niedowierzania, bagatelizowania zdarzeń ofiara doświadcza wtórnego zranienia. Blokuje to działania zmierzające do poszukiwania pomocy i powoduje zmianę myślenia o sytuacji, w której się znalazła. Powtarzające się akty przemocy, brak pomocy i umiejętności radzenia sobie w trudnych sytuacjach powodują, że u ofiary zaczyna kształtować się stan wyuczonej bezradności podtrzymywany przez samego sprawcę, ale też często determinowany wcześniejszymi doświadczeniami ofiary.

W sytuacji, gdy osoba jest krzywdzona przez długi czas, rozwijają się także mechanizmy pozwalające przetrwać w traumatycznej relacji, które jednocześnie ograniczają możliwość uwolnienia się od agresora. Rozwija się między innymi, poza wspomnianym syndromem wyuczonej bezradności, także efekt psychologicznej pułapki, syndrom bitej żony czy symptomy świadczące o PTSD czy syndromie sztokholmskim. Syndrom wyuczonej bezradności (learned helplessness) jest ogólnym wzorcem reagowania na obecność przykrych bodźców, który często pojawia się w wyniku uprzedniego doświadczania przez jednostkę wpływu niezależnych od niej bodźców awersyjnych, których nie mogła uniknąć (Gerring, Zimbardo, 2009, s. 616). Bezradność nie jest więc cechą osobowości, tylko cechą wyuczoną w relacjach np. z partnerem. Powoduje, że ofiara nie podejmuje walki z zagrożeniem. Objawia się biernym znoszeniem przez kobietę zachowań krzywdzących, mimo pełnej świadomości, że zachowania te są bezprawne i naruszają jej prawa osobiste (Budyn-Kulik, 2005, s. 101-104). Następstwem procesu wiktymi- 
zacji bezpośrednio powiązanym z wyuczoną bezradnością jest wystąpienie u pokrzywdzonej syndromu bitej kobiety/żony (battered women syndrome). U ofiary poddawanej cyklicznej przemocy rozwija się cały zespół symptomów, do których zalicza się m.in.: niską samoocenę, poczucie winy, lęk, depresję, podejrzliwość, utratę nadziei, odrętwienie uczuciowe, poczucie piętna, myśli i próby samobójcze. Kobiety te często są przekonane, że nikt, łącznie z nimi, nie jest w stanie udzielić im pomocy. Uczucie beznadziejności towarzyszy ocenie jej związku i prowadzi do przekonania, że jest całkowicie zależną od partnera. Są to także symptomy wyuczonej bezradności. (więcej na ten temat piszą Cipparone, 1987; Mazur, 2002; Gruszczyńska, 2007; Budyn-Kulik, 2005; Dutton, 2002). Innym ze skutków doświadczanej wiktymizacji powiązanym z percepcją związku, jest efekt psychologicznej pułapki. Kobieta ma poczucie, że mimo znacznego zaangażowania w osiągnięcie celu, nie zbliża się do jego realizacji, a prawdopodobieństwo odniesienia sukcesu jest coraz mniejsze. Jednakże ofiara zaangażowała się tak bardzo, a poniesione koszty są tak duże, że mimo świadomości braku sukcesu uporczywie dąży do oddalającego się celu (szczęśliwa rodzina, małżeństwo, szacunek). Efekt psychologicznej pułapki powoduje przechodzenie od aktywnych do pasywnych strategii obronnych (Pospiszyl, 1999, s. 201-202). Znaczącym skutkiem procesu wiktymizacji mogą być także stany związane z występowaniem syndromu postraumatycznego (PTSD), do którego objawów należy zaliczyć afektywne pobudzenie, strach przed utratą kontroli, złość i ograniczona możliwość jej uzewnętrznienia, drażliwość, skłonność do zachowań impulsywnych, gotowość do agresji i nieprzewidywalne wybuchy agresji będące skutkiem obniżenia się zdolności przystosowawczych (Heitzman, 2002, s. 88). Długotrwałość działania stresora powiązanego z przemocą, nieustanne poczucie zagrożenia życia i zdrowia powodować mogą wieloobjawowe konsekwencje psychiczne i emocjonalne. Z tych powodów wyodrębnione zostało pojęcie kompleks PTSD (C-PTSD). Stan C-PTSD różni się od zasadniczego PTSD tym, że charakteryzuje zaburzenie po wielokrotnym stresie związanym przede wszystkim $\mathrm{z}$ traumą $\mathrm{w}$ relacjach interpersonalnych, w których pojawia się przemoc fizyczna, seksualna, zaniedbywanie w dzieciństwie, przemoc fizyczna i seksualna w dorosłości (Pragłowska, Popiel, 2009/1, s. 16). Powyższe konsekwencje wskazują, że skutki wiktymizacji odczuwane mogą być w obszarze interakcji społecznych, błędnej percepcji osoby partnera i związku. Niebezpieczne w skutkach może okazać się utrwalenie wzorów zachowań powodujące zwiększone ryzyko tworzenia kolejnych toksycznych związków z partnerami skłonnymi do stosowania przemocy. Wyjaśnieniem jest identyfikacja z rolą ofiary i antycypacja znanych 
(z zachowania poprzedniego partnera) wzorców, które stwarzają złudne poczucie bezpieczeństwa z tej racji, że są już dobrze znane.

Równie prawdopodobnym następstwem obciążającej sytuacji związanej z przemocą ze strony partnera może być rozwój różnorodnych zaburzeń psychicznych, tj. depresja, zaburzenia lękowe, uzależnienie od alkoholu. W skrajnych przypadkach konsekwencją przedłużającego się stresu, doznawanego przez ofiarę może być nawet samobójstwo. Wspomniane konsekwencje mają charakter trwały, zmieniający w sposób zasadniczy dotychczasowe funkcjonowanie ofiary. Dotyczy to nie tylko jej roli w związku, ale także sposobu pełnienia innych ról życiowych i wchodzenia w interakcje z innymi osobami.

Długotrwałe narażenie na stres powoduje pojawienie się objawów wspomnianego zespołu stresu pourazowego (PTSD). Sygnały te wskazują na postępujący proces wiktymizacji, czyli wchodzenia w rolę ofiary, który powoli zmienia poczucie tożsamości maltretowanej osoby. Opisany mechanizm wyznacza zatem poszczególne etapy (poziomy) procesu wiktymizacji.

Pierwszy poziom wiktymizacji, zwany burzeniem utrwalonych zachowań, charakteryzuje się aktami przemocy, które niszczą utrwalony obraz życia i postrzeganie własnej osoby, na których opierała się dotychczasowa egzystencja człowieka. Maltretowana osoba traci podstawowe poczucie bezpieczeństwa i uporządkowania życia, tracąc zaufanie do innych ludzi oraz do własnej osoby. Czując bunt, rozpacz, niesprawiedliwość i krzywdę, pragnie wycofać się z życia. Na tym etapie poszukuje jeszcze pomocy, starając się przerwać w jakiś sposób sytuację przemocy. W zależności od tego, jaka jest reakcja otoczenia, wiktymizacja może postąpić dalej lub nie. Jeżeli osoba poszukująca pomocy usłyszy, że to, czego doznaje to bezprawna przemoc, otrzyma realną, szybką pomoc - proces może dalej się nie rozwijać.

Drugi poziom wiktymizacji, określany jako wtórne zranienie, jest efektem niewłaściwych reakcji otoczenia na przemoc i próby szukania pomocy przez osobę pokrzywdzoną. Często członkowie rodziny i inne osoby (przyjaciele, znajomi, koledzy i koleżanki z pracy, sąsiedzi czy pracownicy różnych służb) z powodu ignorancji, zmęczenia sytuacją lub bezradnością, zachowują się w taki sposób, który dodatkowo rani krzywdzoną osobę. Przejawia się to w niewierze w to, co mówi ofiara, pomniejszaniu tragizmu i wagi raniących doświadczeń, obwinianiu ofiary lub naznaczaniu jej negatywnymi określeniami. Czasem osoby stykające się z ofiarą odmawiają pomocy lub sugerują, że ofiara chce uzyskać nieuzasadnione korzyści ze swojej sytuacji. U świadków i ludzi próbujących pomagać, zachowanie ofiar przemocy domowej często budzi irytację, gniew, niechęć, bezradność czy rozdrażnie- 
nie. Kierując w stronę osoby pokrzywdzonej uszczypliwe uwagi typu: „jak tyle wytrzymuje, to pewnie to lubi”, ,nie odchodzi, więc widać nie jest to takie straszne”, „sama nie wie, czego chce, więc może potrzebuje twardej ręki”, „jak ją bije to pewnie zasłużyła, przecież wie, co robi”, „wariatka, nie zaszkodzi jak ją trochę potarmosi”. Dużą rolę odgrywają również utrwalone w myśleniu innych ludzi mity („taki to już los kobiety”, „taki jest już ten świat”).

Trzeci, a zarazem ostatni, poziom wiktymizacji nazwany przyjęciem tożsamości ofiary cechuje się tym, że pod wpływem niekorzystnych reakcji otoczenia, powtarzania się aktów przemocy oraz na skutek zmniejszającej się umiejętności radzenia sobie $\mathrm{z}$ urazami, krzywdzona osoba zaczyna przystosowywać się do roli ofiary i przestaje się bronić. Zaczyna myśleć, że bycie ofiarą przemocy jest jej nieuchronnym przeznaczeniem do końca życia. Staje się nietolerancyjna dla własnych słabości i błędów, obwinia się i odmawia sobie podstawowych praw ludzkich, przestając oczekiwać poprawy swojej sytuacji. Traci nadzieję i poczucie godności. W czasie urazu stosuje taktykę przetrwania. Czasem, w ostatnim odruchu desperacji, podejmuje zamach na swoje życie lub życie sprawcy.

U pewnej części ofiar proces wiktymizacji osiąga ten ostatni etap. $\mathrm{Na}$ ogół nie wiadomo, jak często się to dzieje, ponieważ osoby w tym stanie nie szukają pomocy. W sytuacji, gdy ofiara utrwalonej przemocy w rodzinie nie otrzyma wsparcia z zewnątrz, jej szanse na wyrwanie się z pułapki i na uratowanie są znikome (Mellibruda, 2009, s. 28-29).

Zdaniem niektórych autorów możliwe jest stworzenie profilu psychologicznego kobiet - ofiar przemocy partnerskiej natomiast w opinii innych można mówić jedynie o pewnych cechach charakterystycznych, które są efektem sytuacji krzywdzących, w jakich się znalazły. Niezaprzeczalnie jednak osoby doświadczające przez długi czas przemocy wykazują szereg cech sugerujących, jak wspomniano, zmianę ich tożsamości. Jednocześnie cechy te umożliwiają sprawcy kontynuowanie zachowań przemocowych i sprawowanie kontroli nad ofiarą. Wśród najistotniejszych cech znamionujących osobowość ofiary należy wymienić:

- Niskie poczucie własnej wartości będące rezultatem wielokrotnego powtarzania ofierze, że jest głupia, niekompetentna, niewydolna.

- Poczucie braku kontroli nad własnym życiem i braku wiary w możliwość zmiany swojego losu.

- Wstyd, izolacja społeczna i emocjonalna.

- Silna zależność od partnera obejmująca najczęściej sferę finansową, w imię której kobiety godzą się na obelgi i ciężkie obrażenia. 
- $\quad$ Fantazjowanie, łudzenie się, że w jakiś sposób „naprawią lub zmienią" swojego oprawcę.

- Brak umiejętności komunikowania się, szczególnie w zakresie upominania się o swoje prawa i uczucia.

- Przestrzeganie stereotypowych ról dla płci, zwłaszcza wynikających $\mathrm{z}$ reguł systemu patriarchalnego (lekceważenie tych reguł wywołuje poczucie winy).

- Nieumiejętność odróżnienia seksu od miłości i wiara, że miłość przejawia się w intensywnym związku seksualnym (Budyn-Kulik, 2005, Browne, Herbert 1999, Kubacka-Jasiecka, 2010, James, Gilliland, 2004).

Procesowi wiktymizacji sprzyjać mogą zarówno czynniki jednostkowe powiązane z wcześniejszymi doświadczeniami ofiary i utrwalonymi mechanizmami obronnymi, jak i czynniki społeczne i kulturowe, m.in. powiązane ze stereotypami. Wśród mechanizmów obronnych, które stanowią jeden z elementów niepożądanych następstw wiktymizacji należy wymienić wypieranie, tłumienie, dysocjacje i zaprzeczanie. Mechanizmy te kształtują się zazwyczaj pod wpływem silnych traumatycznych wydarzeń (np. doświadczanie przemocy), z którymi psychika dziecka, ale bardzo często i dorosłej ofiary, nie jest w stanie się uporać. Początkowo skutecznie pełnią swoją rolę chroniąc psychikę ofiary, jednak z czasem ulegają one utrwaleniu, ujawniając się w każdej sytuacji trudnej i tym samym blokują podjęcie innych racjonalnych działań. Stanowią one swoiste piętno, z którym ofiara musi mierzyć się całe życie. Utrwalone mechanizmy obronne mogą stać sięźródłem uległości wobec silniejszych, autorytarnych jednostek, powodować zaburzenia osobowości. Do kategorii mechanizmów obronnych, których źródłem mogą być traumatyczne przeżycia powiązane z doznawaniem przemocy należy wypieranie. Jest to mechanizm skutecznie chroniący ofiarę, jednak w dalszej perspektywie staje się ona „zakładnikiem” własnych wypartych wspomnień. Wypieranie bowiem polega na automatycznym i nieświadomym „wyrzucaniu” z pamięci wydarzeń, które są zbyt bolesne, żeby je zapamiętać. Mechanizm wyparcia działa automatycznie. Jednostka „spycha” w podświadomość bolesne doświadczenia, które się już stamtąd nie wydobędą. W związku z tym jednostka nie ma żadnych wspomnień z traumatycznych wydarzeń. Nie znaczy to jednak, że nie rzutuje to na jej zachowanie. Często skutkiem wyparcia są retrospekcje afektywne związane z pojawieniem się bodźca spustowego, który wyzwala w ofierze takie same uczucia, jakich doświadczała w czasie doświadczania pierwotnej traumy (np. podczas wykorzystywania seksualnego). Tym razem jednak ofiara na skutek wypar- 
tych wspomnień nie jest w stanie rozpoznać źródła gwałtownych emocji (np. lęku). Kolejnym mechanizmem jest tłumienie polegające na świadomym zapominaniu bolesnych wydarzeń. W efekcie można przywołać wspomnienia dotyczące tych wydarzeń. Odtworzenie wspomnień najczęściej możliwe jest w trakcie terapii lub przypadkowo (gdy zadziała bodziec spustowy, np. zapach czy słowo, który przywoła wyrywkowe wspomnienia lub lawinowo całość traumy). Z kolei dysocjacje pojawiają się, gdy traumatycznym wydarzeniom nie można zapobiec ani ich przerwać, ani od nich uciec. Istotą dysocjacji jest rozszczepienie (separacja) poczucia rzeczywistości od własnego ciała. Separacja pojawia się w momencie traumy. Wyróżnia się dwie postaci dysocjacji: obserwacja spoza ciała - ofiara obserwuje całe zdarzenie z zewnątrz, jakby w nim nie uczestniczyła, oraz analgezja, czyli znieczulenie - forma pokrewna fizycznemu odrętwieniu. Przypomina stan transu, brak czucia. Ofiary izolują się całkowicie od towarzyszącego im bólu, cierpienia. Natomiast wycofanie to separacja poczucia „ja” od aktualnego otoczenia. Ten mechanizm obronny zwykle stosują dorosłe ofiary (np. podczas terapii czują się zagrożone, że omawianie traumy może naruszyć amnezję i wyzwolić wspomnienia). Dysocjacja i wycofanie z punktu widzenia ofiary to pewne mechanizmy obronne. Bronią psychiki ofiary poprzez odcięcie jej od rzeczywistości. Z drugiej strony burzą możliwość normalnego funkcjonowania. Zaprzeczanie pojawia się, gdy ofierze nie udało się całkowicie odciąć od wspomnień. Osoba wmawia sobie, że zdarzenie, w którym uczestniczyła, nie miało miejsca lub że nie spowodowało takich konsekwencji, jak mówią inni. Wyróżnia się dwa typy zaprzeczeń: zaprzeczanie związane z amnezją - zaprzeczanie, że zdarzenie miało miejsce. Część osób na skutek stłumienia nie pamięta traumy, by nagle po upływie wielu lat przypomnieć sobie zdarzenie. Nagle odtworzony fragment wspomnień może wywołać szok i zaprzeczenie, że miało ono miejsce. Drugą formą jest negowanie wpływu tego wydarzenia na przyszłe życie ofiary - wydarzenie miało miejsce bardzo dawno i nie ma wpływu na to, co się aktualnie dzieje (Grzegołowska-Klarkowska, 1986; Herman, 2000).

Mechanizmy obronne mają na celu chronić ofiarę, ale rzutują też na jej dalsze losy. Pierwsze objawy zaczynają modyfikować psychikę - to depresja lub chroniczny, ostry lęk (najczęściej ich źródłem są retrospekcje afektywne). Ofiara nie jest świadoma tego, co wywołało lęk, strach, rozpacz, pragnienie śmierci, bowiem bodźce spustowe mogą pojawiać się w sytuacjach neutralnych, np. w pracy czy na ulicy. W związku z tym kobieta często izoluje się od innych ludzi, sytuacji które mogą jej zdaniem stanowić źródło nieprzyjemnych retrospekcji. 
Opisane konsekwencje odnoszą się głównie do sfery psychologicznej. Nie można jednak nie dostrzec wpływu na funkcjonowanie zdrowotne czy społeczne. Do odległych konsekwencji należeć będzie także obniżenie walorów życia seksualnego, alergia na bliskość, zaburzenia identyfikacji płciowej, działania autodestrukcyjne, nieporadność w rolach rodzicielskich i partnerskich, wiązanie się z osobami podobnymi do sprawcy (transgeneracyjność) czy stres pourazowy. Doświadczenia te rzutują nie tylko na powielanie pewnych wzorców w relacjach partnerskich, ale wpływają na całokształt interakcji pomiędzy krzywdzoną $w$ dzieciństwie kobietą a mężczyznami oraz innymi kobietami. Wiele z kobiet, które przeżyły w dzieciństwie przemoc (w szczególności seksualną) ujawnia objawy chronicznej traumy, a także występujące w dorosłym życiu zaburzenia poznawcze, emocjonalne i behawioralne. Występują symptomy PTSD, a także niespecyficzne zaburzenia snu czy odżywiania w dorosłym życiu. Oczywiście nie można na tej podstawie wyprowadzić stwierdzenia, że ujawnienie się tego typu zaburzeń ma zawsze podłoże we wcześniejszych, traumatycznych przeżyciach. Można jednak stwierdzić, że dla kobiet, które dokonały zabójstwa partnera lub innego członka rodziny i zdradzają objawy zaburzeń poznawczych, emocjonalnych, a nawet symptomy chorób psychicznych, traumatyczne doświadczenia z dzieciństwa mogły stać się czynnikiem „popychającym je” ku przemocy. Trzeba też wspomnieć, że konsekwencją doświadczanej przemocy, a tym samym i efektów długotrwałego stresu, są także strategie obronne stosowane przez kobiety, które służyć mają przystosowaniu się do sytuacji trudnej, takie jak strategia zmniejszania intensywności przemocy, rozmowy ze sprawcą, pasywnej obrony, unikania czy aktywnej obrony (Mellibruda, 2009; Kluczyńska, 2000).

\section{Wymiana ról ofiary i sprawcy jako następstwo procesu wiktymizacji}

Analizując proces wiktymizacji kobiet ofiar przemocy, które w następstwie tych doświadczeń weszły w role sprawczyń, zwraca uwagę fakt, że doświadczały one szczególnie drastycznych i okrutnych czynów wywołujących ogromne cierpienia. Historia wiktymizacji sprawczyń jest zdecydowanie bardziej okrutna, bolesna i dłużej trwająca niż w przypadku mężczyzn. Badania wskazują, że doświadczana przez kobiety przemoc zwykle powoduje tworzenie relacji o charakterze przemocowym w dorosłym życiu (Gigure, Bumby, 2007). 
Z perspektywy andragogicznego wymiaru doświadczeń życiowych kobiet, które zetknęły się z problemem przemocy domowej istotny jest proces przechodzenia od roli ofiary do roli sprawcy. Zjawisko przekazywania wzorów przemocowych, wyjaśnia koncepcja trójkąta przemocy Philipa Neya. Koncepcja ta zakłada nie tylko bezpośrednią, naprzemienną identyfikację ofiary i sprawcy, ale wskazuje również na możliwość utożsamiania się obserwatora z osobą sprawcy. Sugeruje to, że niedoświadczająca bezpośredniej przemocy jednostka, która staje się jej biernym obserwatorem, jest w takim samym stopniu zagrożona przyswojeniem i podjęciem wzorów zachowań przemocowych jak osoba, która faktycznie jest ofiarą. Zatem nawet jeśli dziecko nie było bezpośrednio narażone na przemoc, ale uczestniczyło w niej biernie, to doświadczenia te mogą wywołać podobne skutki jak u rzeczywistych ofiar tych doświadczeń. Wspomniany model opisujący przemoc w rodzinie zakłada współudział sprawcy, obserwatora i ofiary uwikłanych we wzajemne relacje i tworzących trójkąt. Podstawą wymienności ról jest rotacja trójkąta powodująca zmianę poszczególnych ról. W konsekwencji sprawca w kolejnym epizodzie może wchodzić w rolę ofiary, a ofiara (lub obserwator) w rolę sprawcy. Naprzemienna identyfikacja jest zdaniem Neya możliwa, ponieważ każdy z uczestników „trójkąta przemocy” posiada potencjalne właściwości pozostałych osób uwikłanych w interakcję przemocową. Kierunek rotacji wyznaczony jest każdorazowo względną przewagą cech jednostkowych, okoliczności zewnętrznych, obecnością innych osób, z którymi osoby uwikłane $\mathrm{w}$ doświadczenia przemocowe pozostają $\mathrm{w}$ relacjach (Ney, 1992, s. 17). Obserwowanie przemocy zawsze zaburza wewnętrzną równowagę i zmusza pozornie postronnego uczestnika interakcji do podjęcia określonych działań. Ocena wydarzeń przemocowych, jakiej dokonuje obserwator nigdy nie jest całkowicie obiektywna. Zależy zarówno od czynników indywidualnych, jak i wychowania, które decydują o tym, czy osoba ta będzie tylko obserwatorem określonych wydarzeń, czy aktywnie zareaguje na przemoc. Aktywna lub bierna postawa będzie również stymulować określone zachowanie w zależności od rodzaju przyjętej identyfikacji. Należy jednak podkreślić, że identyfikacja ze sprawcą lub ofiarą może ulegać zmianie pod wpływem czynników zewnętrznych na przykład obecności innych osób. W ten sposób obserwatorzy zyskują możliwość rozwiązania osobistych problemów za pomocą takich działań, które będą dla nich gratyfikujące (Ney, 1992, s. 19-20).

Gdy w relacji sprawca - ofiara, następuje zamiana ról i sprawcą nie jest mężczyzna, lecz kobieta, następuje również zmiana schematu oceny tych zachowań. Przede wszystkim pojawia się tendencja do usprawiedliwiania ak- 
tów przemocy spowodowanych przez kobiety. Tomasz Garstka sugeruje, że nawet jeśli kobieta jest agresorem, to skutki jej działań są dużo mniej dramatyczne niż w sytuacji odwrotnej. Rzadkie są złamania, wstrząsy mózgu, obrażenia wewnętrzne, ślady pobicia. Mężczyźni nawet jako obiekty ataku, zachowują zazwyczaj fizyczna przewagę. W związku z tym są w stanie odeprzeć napaść, a to prowadzić może do „dramatycznego odwrócenia ról ofiary i sprawcy" (Garstka, 1999, s. 18). Wiele destrukcyjnych zjawisk pojawiających się w relacji partnerskiej można uznać za konsekwencje dążenia sprawców do potwierdzania i podnoszenia poczucia własnej wartości oraz potrzeby sprawowania kontroli. Do takich działań zaliczyć należy akty wskazujące na stosowanie przemocy psychicznej oraz dążenie do uzależnienia ofiary od sprawcy. Sprawca dąży do osłabienia i zniszczenia indywidualnej i społecznej tożsamości ofiary poprzez izolowanie jej od innych ludzi, najbliższej rodziny, źródeł potencjalnego wsparcia, pożądanej informacji, pomocy materialnej, a nawet przedmiotów symbolizujących bliskie więzi z innymi, jak fotografie, korespondencja, pamiątki (Majchrzyk, 2008, s. 142).

Oczywiście nie w każdym wypadku przemoc doświadczana w dzieciństwie i powiązany z nią proces wiktymizacji będzie miał związek ze zmianą ról ofiary na sprawczynię. Wiele kobiet nigdy w rolę sprawcy przemocy nie wchodzi. Można raczej stwierdzić, że to pewien typ doświadczeń wiktymizacyjnych, typ zachowania, które reprezentowały osoby ze środowiska, w którym miało miejsce wydarzenie, przyczyniły się do psychicznego i społecznego niedostosowania, późniejsze sięganie po środki psychoaktywne oraz wchodzenie w dysfunkcyjne związki będące powieleniem relacji ze sprawcą, należy uznać za czynniki, które pozostają w związku z późniejszymi aktami przemocy nie wyłączając tych, które mają najbardziej drastyczne zakończenie (por. Eldridge, Saradjian, 2000, [w:] Laws, Hudson, Wards, s. 402-426).

\section{Podsumowanie}

Reasumując można zauważyć, że proces wiktymizacji, który inicjują traumatyczne doświadczenia życiowe, powoduje kształtowanie tożsamości ofiary, której najważniejszą cechą jest wyuczona bezradność życiowa. Konsekwencje obejmują zmiany osobowościowe, emocjonalne, psychiczne, a nierzadko także wpływają na losy życiowe ofiar, w przebiegu których śmierć ofiary lub sprawcy przemocy stanowi najbardziej tragiczny scenariusz. Proces wiktymizacji postrzegać można w związku z tym jako swoistą metamorfo- 
zę, w trakcie której ofiara przemocy i powiązanych z nią traumatycznych doznań staje się również sprawcą, w wyniku czego dochodzi do zabójstwa partnera życiowego. Ten szczególny typ zabójstw (oczywiście należy wspomnieć, że zabójstwa dokonane przez kobiety nie zawsze muszą wiązać się z procesem wiktymizacji) motywowany jest zwykle obroną własną, poczuciem zagrożenia i lękiem. Niestety ukształtowana tożsamość ofiary powiązana z bagażem doświadczeń, specyficznymi mechanizmami obronnymi, cechami osobowości i zachowaniami takimi jak: niska samoocena, poczucie winy, lęk, depresja, podejrzliwość, utrata nadziei, odrętwienie uczuciowe, poczucie piętna, myśli i próby samobójcze, nie poddaje się łatwo rekonstrukcji powodując permanentne problemy w interakcjach $\mathrm{z}$ innymi ludźmi i przekonane, że nikt, łącznie z nimi, nie jest w stanie udzielić im pomocy. Uczucie beznadziejności towarzyszy ocenie jej związku i prowadzi do przekonania, że jest całkowicie zależną od partnera.

\section{Bibliografia}

Browne K., Herbert M. (1999), Zapobieganie przemocy w rodzinie, Państwowa Agencja Rozwiązywania Problemów Alkoholowych, Warszawa.

Budyn-Kulik M. (2005), Zabójstwo tyrana domowego. Studium kryminologiczno- wiktymologiczne, Oficyna Wydawnicza Verba, Lublin.

Cipparone R.C. (1987), The defence battered women who kill, „University of Pennsylvania Law Review", Vol. 135:427.

Dutton M.A. (1994), The Dynamic of Domestic Violence, „The Floryda Bar Jurnal/October”, za: Ewa Bilska, Przychodzi sprawca do lekarza, „Niebieska Linia, 1999, nr 3.

Eldridge H.J., Saradjian J. (2000), Replacing the function of abusive behaviors for the offender: Remaking relapse prevention in working with women who sexually abuse children. [w:] D.R. Laws, S.M. Hudson, T. Wards, Remaking relapse prevention with sex offenders, A sourcebook, Thousands Oaks.

Gerrig R.J., Zimbardo P.G. (2009), Psychologia i życie. Wydanie nowe, Wydawnictwo Naukowe PWN, Warszawa.

Gigure R., Bumby K.(2007), Female sex offenders. za: Ashfeld S., Brotherstone S., Eldridge

H., (2010). Working with female sexual offenders: Therapeutic Process Issues. [w:] T.A. Gannon, F. Cortoni (red.), Female Sexual Offenders; Theory, Assessment and Treatment, John Wiley \& Sons Ltd, London.

Garstka T. (1999), Gdy bije kobieta. „Niebieska Linia”, nr. 3. 
Grzegołowska-Klarkowska J.H. (1986), Mechanizmy obronne osobowości. [w:] J. Strelau (red.), Psychologia, PWN, Warszawa.

Gruszczyńska B. (2007), Przemoc wobec kobiet w Polsce. Aspekty prawno-kryminologiczne, Wolters Kluwer Polska, Warszawa.

Heitzman J. (2002), Stres w etiologii przestępstw agresywnych, Wydawnictwo Uniwersytetu Jagiellońskiego, Kraków.

Herman J.L.(2000), Przemoc. Uraz psychiczny i powrót do równowagi, Wydawnictwo GWP, Gdańsk.

Hołyst B. (2006), Wiktymologia, Wydawnictwo Prawnicze PWN, Warszawa.

James R.K., Gilliland B.E. (2004), Strategie interwencji kryzysowej, PARPA, Warszawa.

Kluczyńska S. (2000), Dlaczego kobiety zostają?, „Niebieska Linia”, nr 4.

Kubacka-Jasiecka, D. (2010), Interwencja kryzysowa. Pomoc w kryzysach psychologicznych, Wydawnictwa Akademickie i Profesjonalne, Warszawa.

Majchrzyk Z. (2008), Zabójczynie i zabójcy: osobowość, motywy, uwarunkowania sytuacyjne: analiza z perspektywy psychologicznego orzecznictwa sqdowego, Wydawnictwo UKSW, Warszawa.

Mazur J. (2002), Przemoc w rodzinie. Teoria i rzeczywistość, Wydawnictwo akademickie Żak, Warszawa.

Mellibruda J. (2009), Przeciwdziałanie przemocy domowej, Instytut Psychologii Zdrowia, Warszawa.

Ney P.H. (1992), Transgenerational Triangle of Abuse. A Model of Family Violence, [w:] E.C. Viando (red.), Intimate violence. Interdisciplinary Perspectives, Bristol.

Pospiszyl I. (1999), Razem przeciw przemocy, PWN, Warszawa.

Pragłowska E., Popiel A. (2009), Przemoc jako trauma wielomodalna. Między przemocq a PTSD, „Niebieska Linia”, nr 1.

Rubacha K. (2008), Metodologia badań nad edukacją, Wydawnictwo Akademickie i Profesjonalne, Warszawa. 